\title{
Penurunan Bod dan Cod Limbah Cair Industri Batik Menggunakan Karbon Aktif Melalui Proses Adsorpsi Secara Batch
}

\author{
Nikmatul Rochma dan Harmin Sulistyaning Titah \\ Departemen Teknik Lingkungan, Fakultas Teknik Sipil dan Perencanaan, Institut Teknologi Sepuluh Nopember \\ (ITS) \\ e-mail: harmin_st@its.ac.id
}

\begin{abstract}
Abstrak-Industri tekstil merupakan pendukung pertumbuhan ekonomi di Kota Sidoarjo. Semakin tinggi permintaan tekstil batik, dapat meyebabkan peningkatan yang seimbang antara produksi dan limbah produksi. Kandungan limbah batik dengan zat organik seperti BOD dan COD yang tinggi, dapat menyebabkan pencemaran lingkungan. Penelitian ini bertujuan untuk mengetahui efisiensi karbon aktif batu bara pada proses adsorpsi. Karbon diaktivasi terlebih dahulu, bertujuan untuk mengoptimalkan kinerja absorben selama proses adsorpsi. Aktivator yang digunakan adalah larutan kimia asam kuat-HCL. Penelitian ini menggunakan variasi absorben 86 gram, 190 gram, dan 278 gram. Sedangkan waktu kontak yang digunakan 2,5 jam dan 5 jam. Penelitian skala laboratorium ini menggunakan alat yang sederhana namun bersifat aplikatif dengan menggunakan botol bekas air mineral. Berdasarkan proses adsorpsi yang dilakukan, efisiensi penyisihan COD terbesar adalah 16.444,08 $\mathrm{mg} / \mathrm{L}$. Dengan persentase penyisihan sebesar $98,74 \%$ pada waktu kontak 2,5 jam. Sedangkan efisiensi penyisihan BOD terbesar adalah 1.640,70 $\mathrm{mg} / \mathrm{L}$. Dengan persentase penyisihan sebesar 92,30 \% pada waktu kontak 2,5 jam. Jumlah adsorben yang menghasilkan nilai efisiensi penyisihan tersebut adalah sebesar 190 gram. Didapatkan juga isoterm yang paling tepat adalah isoterm $B E T$. Dengan nilai $Y=0,5881 \ln (x)+2,22$ dan nilai Regresinya $\left(R^{2}\right) 0,8295$. Berdasarkan perhitungan isoterm model $B E T$, proses adsorpsi yang terjadi adalah adsorpsi secara fisika dan multilayer. Setelah proses adsorpsi akan dilakukan analisa karbon menggunakan Scanning Electron Microscope (SEM). Untuk mengetahui perbedaan permukaan sebelum dan sesudah proses adsorpsi dilakukan. Hasil Analisa SEM menunjukkan bahwa rongga yang mulanya masih kosong telah tertutupi oleh adsorbat yang teradsorpsi. Adsorpsi terjadi pada multilayer pada pori karbon aktif yang terlihat berdasarkan hasil foto SEM. Kesimpulannya, karbon aktif ini dapat digunakan sebagai adsorben untuk menghilangkan zat organik BOD dan COD pada limbah cair industri batik
\end{abstract}

Kata Kunci-Adsorpsi, Karbon Aktif, Limbah Industri Batik , SEM.

\section{PENDAHULUAN}

$\mathrm{K}^{\prime}$ AMPUNG Batik Jetis di Sidoarjo merupakan home industry dengan batik tulisnya. Kampung Batik Jetis terdiri dari beberapa home industry yang tergabung menjadi sebuah kelompok perajin batik. Kelompok perajin tersebut telah diresmikan oleh pemerintah setempat. Permasalahan yang terjadi pada kampung batik ini adalah tidak adanya IPAL yang digunakan untuk mengolah limbah yang dihasilkan.
Tidak adanya IPAL dikarenakan tidak tersedianya lahan yang cukup untuk pembangunan IPAL pada Kampung Batik Jetis. Oleh karena itu, para perajin batik membuang limbah secara langsung ke sungai di dekat tempat produksi. Limbah yang dibuang ke sungai mengandung pencemar bahan organik dengan kadar yang sangat tinggi, dan hal itu dapat mencemari sungai. [1] menyatakan bahwa dalam membatik terdapat tiga proses yang dilakukan, yaitu proses pemalaman, pewarnaan, dan pelorodan. Pada proses membatik juga banyak menggunakan bahan kimia dan air. Pada penelitian sebelumnya terdapat proses pewarnaan dengan kandungan pencemar Biochemical Oxygen Demand (BOD) sebesar $1.777,5 \mathrm{mg} / \mathrm{L}$. Chemical Oxygen Demand (COD) sebesar $16.654,8 \mathrm{mg} / \mathrm{L}$. Total Suspended Solid (TSS) sebesar 208 mg/L [2]. Berdasarkan peraturan Gubernur Jawa Timur No.72 Tahun 2013 tentang Baku Mutu Air Limbah Industri atau Kegiatan Usaha Lainnya di Jawa Timur. Khusus untuk industri tekstil baku mutu limbah cair untuk parameter COD sebesar $150 \mathrm{mg} / \mathrm{L}$, parameter BOD sebesar $50 \mathrm{mg} / \mathrm{L}$. Sehingga berdasarkan peraturan tersebut limbah cair yang dihasilkan perajin batik melebihi baku mutu limbah cair yang berlaku di Jawa Timur.

Penelitian ini akan melakukan pengolahan limbah menggunakan proses adsorpsi. Pada proses adsorpsi akan dilakukan dengan menggunakan adsorben dari karbon aktif. Karbon aktif akan diaktifkan dengan $\mathrm{HCl}$ untuk memperbesar pori karbon. Sehingga proses adsorpsi akan lebih efektif. Berdasarkan penelitian yang dilakukan sebelumnya [3] larutan asam sebagai aktivator karbon seperti $\mathrm{H}_{2} \mathrm{SO}_{4}, \mathrm{HCl}$ dan $\mathrm{H}_{3} \mathrm{PO}_{4}$, paling efisien adalah HCL. Pada penelitian yang akan dilakukan proses pengolahan mengggunakan sistem adsorpsi secara Batch. Kelebihan yang terdapat pada penelitian ini terletak pada adsorban yang digunakan. Adsorban merupakan bahan yang mudah ditemui di toko bahan pada pengolahan air minum atau air limbah. Harga adsorban juga cukup ekonomis bila digunakan. Hal yang membuat karbon aktif cukup ekonomis adalah sifatnya yang mudah untuk dibersihkan. Kemudian diaktifkan kembali sehingga dapat digunakan berulang-ulang sampai dengan batas maksimal pemakaiannya. Kelebihan lainnya terdapat pada proses pengolahan limbah pada penelitian ini juga mudah diaplikasikan oleh perajin batik. Karena tidak memerlukan lahan yang cukup luas untuk meletakkan reaktor pengolahannya. 


\section{METODE PENELITIAN}

\section{A. Analisa Karakteristik Limbah}

Pada penelitian pendahuluan yang telah dilakukan didapatkan karakteristik awal air limbah pewarnaan sebagai karakteristik awal limbah tersebut. Analisa laboratorium dilakukan oleh Badan Riset dan Standarisasi Penelitian Limbah Industri (BARISTAN) Surabaya dapat dilihat pada Tabel 1.

Tabel 1.

Karakteristik Limbah Batik

\begin{tabular}{ccccc}
\hline \hline No & Parameter Uji & Satuan & Hasil Uji & $\begin{array}{c}\text { Persyaratan } \\
\text { Mutu (*) }\end{array}$ \\
\hline 1 & BOD $_{5}$ & $\mathrm{mg} / \mathrm{L}$ & 1777,5 & 50 \\
2 & $\mathrm{COD}$ & $\mathrm{mg} / \mathrm{L}$ & $16.654,80$ & 150 \\
3 & $\mathrm{TSS}$ & $\mathrm{mg} / \mathrm{L}$ & 208 & 50 \\
4 & Phenol & $\mathrm{mg} / \mathrm{L}$ & 4,28 & 0,5 \\
5 & $\mathrm{Cr}$ & $\mathrm{mg} / \mathrm{L}$ & $<0,0201$ & 1 \\
6 & $\mathrm{pH}$ & - & 9,3 & \\
\hline \hline
\end{tabular}

*Baku Mutu [4]

Sumber: Hasil Analisa Laboratorium oleh BARISTAN, Surabaya.

\section{B. Uji Fisik Media}

Uji Fisik Media karbon aktif dapat diperlihatkan melalui beberapa pengujian mutu arang aktif. Pengujian tersebut meliputi penentuan densitas media ,kadar air, kadar abu dan daya adsorp terhadap iodium [5].Hasil yang diperoleh diharap menjadi data pendukung penelitian untuk melakukan penelitian selanjutnya. Data hasil uji pendahuluan dapat dilihat pada Tabel 2 .

Tabel 2.

Uji Fisik Media

\begin{tabular}{|c|c|c|c|}
\hline Karakteristik & Hasil & $\begin{array}{c}\text { Standart Max } \\
{[6]}\end{array}$ & Satuan \\
\hline Ketahanan Fisik & 0,09 & & $\%$ \\
\hline \multicolumn{4}{|c|}{ Densitas Media } \\
\hline True Bulk Density & 1,152 & & $\mathrm{gram} / \mathrm{ml}$ \\
\hline Apparent Density & 0,44 & $\pm 0,45$ & $\mathrm{gram} / \mathrm{ml}$ \\
\hline Kadar Air & 2,7 & 4,4 & $\%$ \\
\hline Kadar Abu & 1,4 & 2,5 & $\%$ \\
\hline Porositas & 1,04 & 5 & $\%$ \\
\hline
\end{tabular}

Sumber: Penelitian di Laboratorium Teknik Lingkungan

\section{Penentuan Masa Adsorban}

Masa adsorban yang digunakan pada penelitian ini ditentukan berdasarkan pertimbangan pada literatur penelitian yang terdahulu. Masa adsorban karbon aktif yang digunakan pada penelitian ini adapat dilihat pada Tabel 3.

Berdasarkan pertimbangan literatur pada Tabel 3, penelitian ini menggunakan massa adsorban sebanyak 89 gram, 190 gram, dan 278 gram. Hal ini juga berdasarkan pertimbangan kolom reaktor adsorpsi yang digunakan sangat sederhana (botol bekas air mineral). Sehingga penentuan massa adsorban beracuan pada tinggi dasar botol. Dengan rentang variasi ketinggian $2 \mathrm{~cm}$ (tinggi botol 5,5 cm; 7,5 cm; 9,5 cm).

Tabel 3.

Penentuan Masa Adsorban

\begin{tabular}{|c|c|c|c|}
\hline No. & $\begin{array}{l}\text { Massa Adsorban } \\
\text { (gram) }\end{array}$ & Acuan Terdahulu & $\begin{array}{l}\text { Adsorban } \\
\text { Penelitian }\end{array}$ \\
\hline
\end{tabular}

\begin{tabular}{cccc}
\hline \hline & & & (gram)* $^{*}$ \\
\hline 1 & $125 ; 250 ; 375 ; 500$ & Wahyunanto, 2015 & \\
2 & $25 ; 50 ; 100$ & Jannatin, 2010 & $80 ; 190 ; 278$ \\
3 & $2 ; 3 ; 5 ; 10 ; 15$ & Ademiluyi, 2009 & \\
\hline \hline
\end{tabular}

\section{Reaktor Batch}

Reaktor adsorpsi batch terbuat dari botol bekas air mineral yang memiliki kapasitas $1500 \mathrm{~mL}$. Botol bekas yang telah disiapkan kemudian dibersihkan dan lepaskan semua brand yang menempel pada permukaan bagian luar botol. Setelah dibersihkan dilakukan proses pengeringan dan pemotongan dasar botol mengikuti lingkar botolnya. Kemudian bagian atas botol (mulut botol) beri lapisan plastik atau kain untuk menahan karbon tidak lolos dari dalam botol. Kemudian pada permukaan botol tersebut dilakukan pengukuran $(5,5 \mathrm{~cm} ; 7,5$ $\mathrm{cm}$; dan $11,5 \mathrm{~cm}$ ) dari mulut botol. Hal tersebut dilakukan untuk meletakkan karbon karbon aktif yang akan digunakan pada proses adsoprsi. Pengukuran pada botol diakhiri dengan pemberian tanda hasil pengukuran pada masing-masing botol.

\section{HASIL DAN PEMBAHASAN}

\section{A. Pengaruh Adsorpsi secara Batch}

Penelitian ini menggunakan metode adsorpsi secara batch dalam mereduksi parameter pencemar limbah batik yang diujikan. Proses adsorpsi bertujuan untuk menyisihkan zat organik seperti BOD dan COD. Berikut adalah hasil perhitungan penyisihan BOD dan COD dapat dilihat pada Tabel 4.

Tabel 4. Perhitungan Penyisihan

\begin{tabular}{cccccc}
\hline \hline & & \multicolumn{4}{c}{ Penyisihan } \\
\cline { 3 - 6 } No & Sampel & $\begin{array}{c}\text { BOD 2,5 } \\
\text { jam } \\
(\mathrm{mg} / \mathrm{L})\end{array}$ & $\begin{array}{c}\text { BOD 5 } \\
\text { jam } \\
(\mathrm{mg} / \mathrm{L})\end{array}$ & $\begin{array}{c}\text { COD 2,5 } \\
\text { jam } \\
(\mathrm{mg} / \mathrm{L})\end{array}$ & $\begin{array}{c}\text { COD 5 } \\
\text { jam } \\
(\mathrm{mg} / \mathrm{L})\end{array}$ \\
\hline 1 & Blanko & - & - & - & - \\
2 & Adsorpsi I & 1569,50 & 1605,90 & 16364,80 & 16454,80 \\
3 & Adsorpsi II & 1614,75 & 1657,50 & 16404,80 & 16414,80 \\
4 & Adsorpsi III & 1640,70 & 1681,95 & 16444,80 & 16434,80 \\
5 & Adsorpsi IV & 1665,75 & 1713,15 & 16474,80 & 16504,80 \\
6 & Adsorpsi V & 1705,50 & 1728,15 & 16454,80 & 16504,80 \\
7 & Adsorpsi VI & 1720,70 & 1742,75 & 16494,80 & 16534,80 \\
\hline \hline
\end{tabular}

\section{B. Pengaruh terhadap COD}

Analisis Chemical Oxygen Demand (COD) pada penelitian ini menggunakan metode reflux yang dilakukan di Laboratorium Pemulihan Kualitas Air. Analisis ini dilakukan untuk mengetahui perubahan pencemar kimia-organik pada air limbah batik (proses pewarnaan). Setelah dilakukan proses adsorpsi maka efluen hasil adsorpsi akan di analisa beban kimia-organiknya (COD). Berikut adalah hasil penyisihan parameter pencemar yang didapatkan setelah proses adsorpsi dapat dilihat pada Gambar 1. 


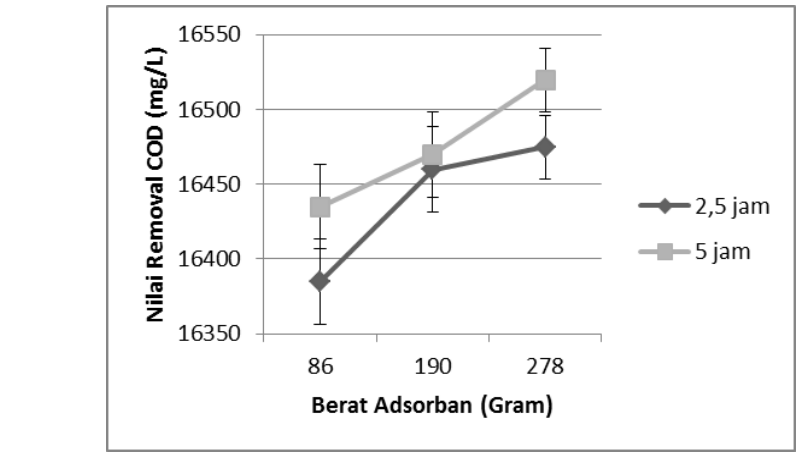

Gambar 1. Penyisihan COD setelah proses Adsorpsi.

Berdasarkan grafik pada Gambar 1. didapatkan nilai COD dari proses adsorpsi waktu kontak 5 jam berkecenderungan menurunkan BOD lebih tinggi. Namun berdasarkan Gambar 1. di atas pada waktu 2,5 jam efisiensi penurunan COD juga cukup tinggi.

\section{Pengaruh terhadap BOD}

Analisis Biochemical Oxygen Demand (BOD) pada penelitian menggunakan ini metode winkler yang dilakukan di Laboratorium Pemulihan Kualitas Air. Analisis ini dilakukan untuk mengetahui perubahan pencemar organik pada air limbah batik (proses pewarnaan). Hasil perhitungan penyisihan parameter pencemar yang didapatkan setelah proses adsorpsi dapat dilihat pada Gambar 2.

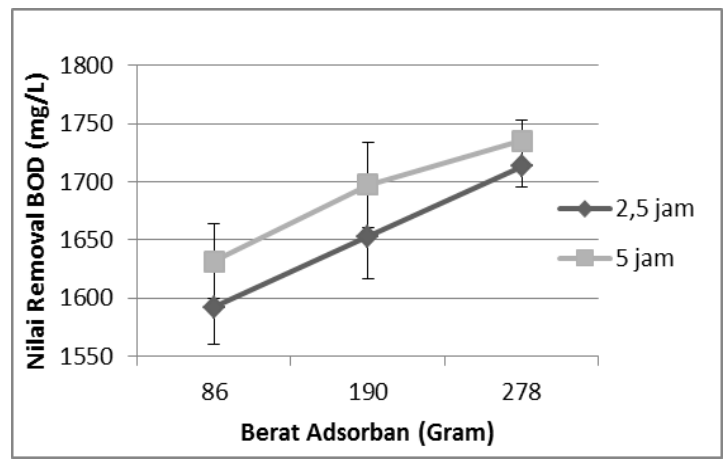

Gambar 2. Penyisihan BOD setelah proses Adsorpsi.

Berdasarkan grafik pada Gambar 2. didapatkan nilai BOD dari proses adsorpsi waktu kontak 5 jam berkecenderungan menurunkan BOD lebih tinggi. Namun berdasarkan Gambar 2 . di atas pada waktu 2,5 jam efisiensi penurunan BOD juga cukup tinggi. Sehingga didapatkan penurunan BOD efisien pada waktu 2,5 jam dengan massa karbon aktif sebanyak 190 gram. Hal itu digunakan untuk mendapatkan efisiensi penurunan yang besar, namun menggunakar karbon yang sedikit. Supaya saat penelitian ini diaplikasikan dapat meminimalisir biaya pengolahan limbah.

Pernyataan tersebut didukung dengan penelitian pendukung yang telah dilakukan. Penelitian ini menggunakan limbah batik dengan massa adsorban sebanyak 190 gram. Proses adsorpsi dilakukan selama \pm 4 jam (2 jam lebih lama dari variabel waktu pada penelitian sebelumnya). Hasil dari penelitian ini menyatakan bahwa penurunan setelah waktu kontak 2,5 jam tidak terjadi perubahan yang sangat sigifikan. Walaupun pada adsorban masih berlangsung proses adsorpsi. Hasil tersebut dapat dilihat pada Gambar 3.

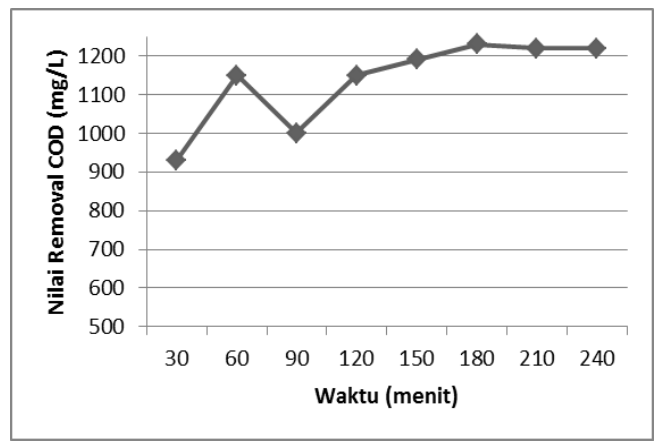

Gambar 3. Penyisihan COD setelah proses Adsorpsi.

Pada Gambar 3. adsorban mengadsorpsi limbah pada 2 jam pertama. Untuk proses adsorpi selanjutnya cenderung konstan. Adapun perbedaan penurunan yang terjadi tidak begitu besar. Sehingga waktu kontak 2,5 jam sudah cukup untuk melakukan proses adsorpsi pada penelitian ini.

\section{Isoterm Langmuir}

Isotherm adsorpsi Langmuir didasarkan atas beberapa asumsi, yaitu: Adsorpsi hanya terjadi pada lapisan tunggal (monolayer). Panas adsorpsi tidak tergantung pada penutupan permukaan. Untuk membuktikan asumsi tersebut sesuai atau tidak dengan proses adsorpsi pada penelitian ini, dinyatakan dalam bentuk isoterm adsorpsi. Dimana massa adsorbat yang teradsorpsi digambarkan sebagai fungsi dari konsentrasi setimbang (konsentrasi akhir). Berikut adalah grafik dari isoterm Langmuir dapat dilihat pada Gambar 4. dan 5.

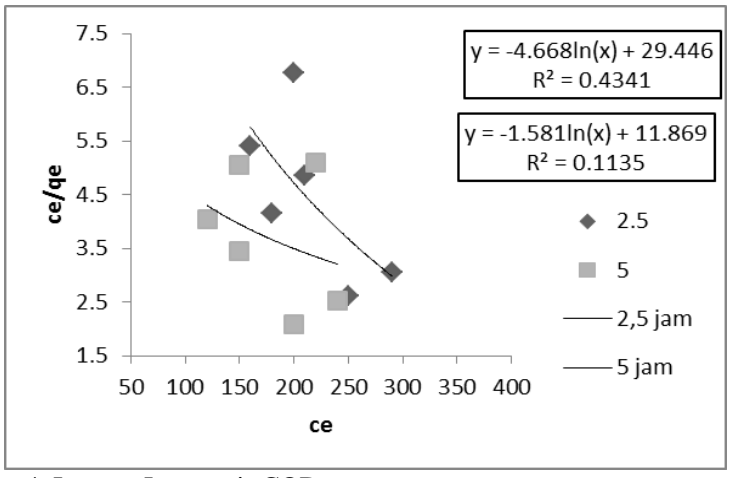

Gambar 4. Isoterm Langmuir COD.

Berdasarkan grafik Isoterm Langmuir pada Gambar 4.5 Parameter COD, didapatkan persamaan linier $\mathrm{Y}=-4.668 \ln (\mathrm{x})$ +29.446 dalam waktu 2,5 jam. Sedangkan nilai $\mathrm{Y}=$ $1.581 \ln (\mathrm{x})+11.869$ dalam waktu $5 \mathrm{jam}$. Dengan nilai regresi $\left(R^{2}\right) 0.4341$ dan 0.1135 .

Berdasarkan grafik Isoterm Langmuir pada Gambar 4.4 Parameter Parameter BOD Persamaan linier $\mathrm{Y}=1,9867 \ln (\mathrm{x})+$ 13,791 dalam waktu 2,5 jam. Sedangkan nilai $Y=3,3333 \ln (x)$ $+1,1074$ dalam waktu $5 \mathrm{jam}$. Dengan nilai regresi $\left(\mathrm{R}^{2}\right) 0,0355$ dan 0,2567. Sehingga Isoterm Langmuir tidak tepat digunakan dalam penelitian ini. Karena dengan nilai $\mathrm{R}^{2}$ semakin kecil daripada nilai 1. 


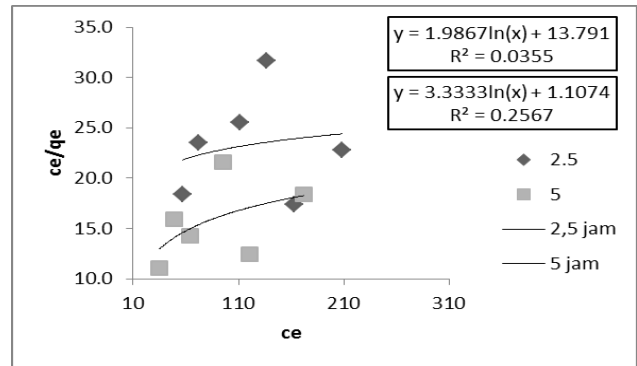

Gambar 5. Isoterm Langmuir BOD.

\section{E. Isoterm Freundlich}

Isoterm Freundlich sering digunakan dalam adsorpsi pada zat cair. Asumsi dari isoterm ini didasarkan atas beberapa asumsi, yaitu: Terbentuknya lapisan monolayer dari molekulmolekul adsorbat pada permukaan adsorben. Namun ada pula adsorpsi pada permukaan adsorben bersifat heterogen. Untuk membuktikan asumsi tersebut sesuai atau tidak dengan proses adsorpsi pada penelitian ini, dinyatakan dalam bentuk isoterm adsorpsi. Dimana massa adsorbat yang teradsorpsi digambarkan sebagai fungsi dari konsentrasi setimbang (konsentrasi akhir). Berikut adalah grafik dari isoterm Freundlich dapat dilihat pada Gambar 6. dan 7.

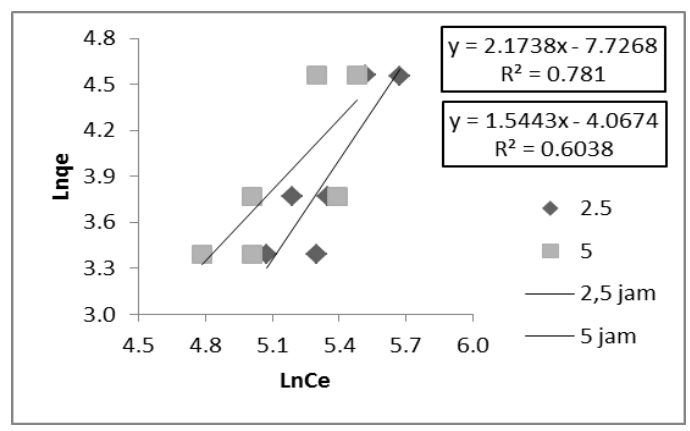

Gambar 6. Isoterm Freundlich COD.

Berdasarkan grafik Isoterm Freundlich pada Gambar 7. Parameter COD, didapatkan persamaan linier $\mathrm{Y}=2,1738 \mathrm{x}$ 7,7268 dalam waktu 2,5 jam. Sedangkan nilai $Y=1,5443 x-$ 4,0674 dalam waktu 5 jam. Dengan nilai regresi $\left(R^{2}\right) 0,781$ dan 0,6038 .

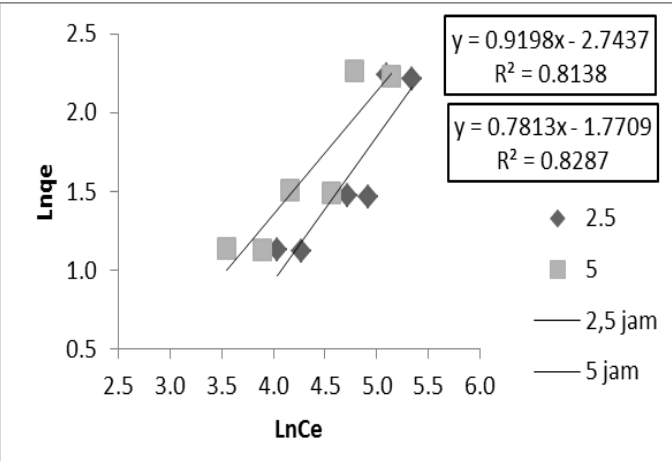

Gambar 8. Isoterm Freundlich BOD.

Berdasarkan grafik Isoterm Freundlich pada Gambar 4.6 Parameter BOD Persamaan linier $\mathrm{Y}=0,9198 \mathrm{x}-2,7437$ dalam waktu 2,5 jam. Sedangkan nilai $\mathrm{Y}=0,7813 \mathrm{x}-1,7709$ dalam waktu 5 jam. Dengan nilai regresi $\left(R^{2}\right) 0,8138$ dan 0,8287 .
Sehingga Isoterm Freundlich tepat digunakan dalam penelitian ini. Karena dengan nilai $\mathrm{R}^{2}$ semakin mendekati nilai 1 .

\section{F. Isoterm BET}

Teori BET menjelaskan bahwa adsorbsi terjadi di atas lapisan adsorbat monolayer. Sehingga, isotherm adsorbs BET dapat diaplikasikan untuk adsorbs multilayer. Untuk membuktikan asumsi tersebut sesuai atau tidak dengan proses adsorpsi pada penelitian ini, dinyatakan dalam bentuk isoterm adsorpsi. Dimana massa adsorbat yang teradsorpsi digambarkan sebagai fungsi dari konsentrasi setimbang (konsentrasi akhir). Berikut adalah grafik dari isoterm Freundlich dapat dilihat pada Gambar 4.8 dan 4.9.

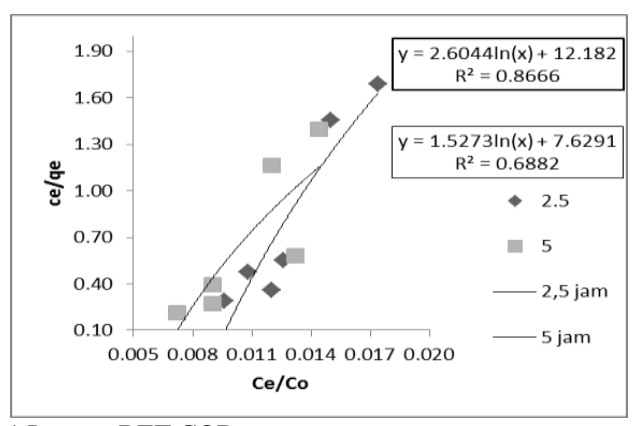

Gambar 4. 1 Isoterm BET COD.

Berdasarkan grafik Isoterm BET pada Gambar 4.8 Parameter COD, didapatkan persamaan linier. Persamaan linier tersebut adalah nilai $\mathrm{Y}=2,6044 \ln (\mathrm{x})+12,182$ dalam waktu 2,5 jam. Sedangkan nilai $\mathrm{Y}=1,5273 \ln (\mathrm{x})+7,6291$ dalam waktu 5 jam. Dengan nilai regresinya 0,8666 dan 0 , 6882 .

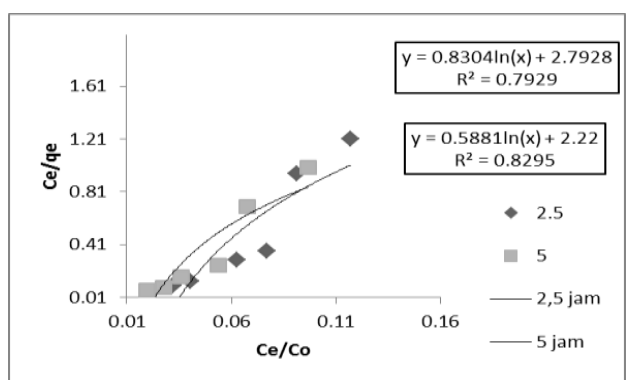

Gambar 4. 2 Isoterm BET BOD.

Berdasarkan grafik Isoterm BET pada Gambar $4.9 \ln (\mathrm{x})+$ 12,182 82 dalam waktu 2,5 jam. Sedangkan nilai $\mathrm{Y}=1,5273 \ln (\mathrm{x})+7,6291$ dalam waktu 5 jam. Dengan nilai regresi $\left(R^{2}\right) 0,8666$ dan 0,6882 .

Jika dilihat dari data koefisien korelasi maka dari semua grafik tersebut, nilai $\mathrm{R}^{2}$ mendekati angka satu terdapat pada metode isoterm Freundlich $(0,7810 \& 0,8138)$. Nilai $\mathrm{R}^{2}$ yang mendekati angka satu juga terdapat pada isoterm BET $(0,8666$ $\& 0,7929)$. Namun diantara keduannya dapat ditentukan yang paling tepat adalah isoterm BET. Karena nila $\mathrm{R}^{2}$ pada penurunan COD lebih mendekati angka 1 (Penurunan COD akan berbanding lurus dengan penurunan BOD). Bila konsentrasi pencemar organik menurun, maka akan meningkatkan kualitas air limbah hasil proses adsorpsi. Sehingga dapat disimpulkan bahwa adsorpsi beban organik 
menggunakan karbon aktif pada penelitian ini mengikuti model BET. Adsorpsi BET merupakan proses adsorpsi secara batch yang terjadi secara fisika. Terjadi pada multilayer dan semua molekul di luar lapisan pertama memiliki energi yang sama untuk adsorpsi. Adsorpsi yang terjadi karena adanya interaksi secara fisik antara adsorbat ( zat yang diserap) dengan permukaan adsorben (zat yang menyerap).

\section{G. Kapasitas Adsorpsi}

Berdasarkan persamaan linier grafik BET didapat persamaan garis linier dan regresi untuk mendapatkan persamaan BET. Nilai $\mathrm{q}(\mathrm{x} / \mathrm{m})$ karbon aktif adalah:

$\mathrm{y}=0,5881 \ln (\mathrm{x})+2,22$

$$
\begin{aligned}
\mathrm{kb} \quad & =0,5881 \ln \left(\frac{C}{C_{\mathrm{o}}}\right)+2,22 \\
& =0,5881 \ln (0,097)+2,22 \\
& =0,848 \mathrm{mg} / \mathrm{L}
\end{aligned}
$$

Konstanta Kecepatan Adsorpsi (kb) : 0,848 mg/L.

Dengan persamaan dari grafik isoterm BET didapatkan nilai intercept 2,22, maka nilai qo dapat ditentukan dengan rumus:

$$
\begin{array}{ll}
\text { intercept } & =\frac{1}{K_{b \times q 0}} \\
2,22 & =\frac{1}{0,049 \times q 0} \\
\text { qo } & =\frac{1}{0,249 \times 2,22} \\
\text { qo } & =0,531 \mathrm{mg} / \mathrm{L}
\end{array}
$$

Kapasitas Adsorpsi (qo): 0, $531 \mathrm{mg} / \mathrm{L}$

\subsection{Scanning Electron Microscope (SEM)}

Adapun hasil analisa Scanning Electron Microscope (SEM) pada adsorban dalam penelitian ini dilakukan di Laboratorium Energi kampus ITS, Surabaya. Analisa SEM dilakukan untuk mengetahui kondisi permukaan kabon. Sehingga dapat dilakukan perbandingan permukaan karbon aktif sebelum dan sesudah dilakukan proses adsorpsi. hasil analisa SEM dapat dilihat pada Gambar 4.10 hingga Gambar 4.13.

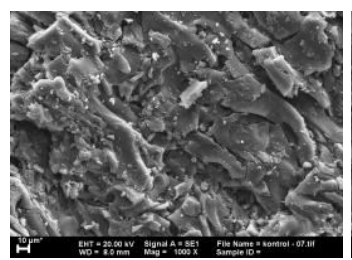

(a)

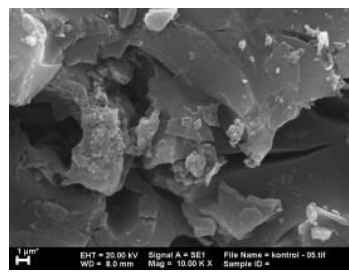

(c)

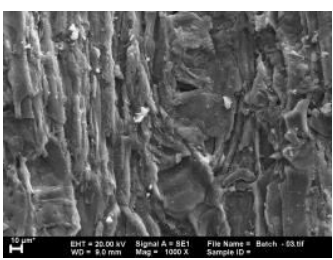

(b)

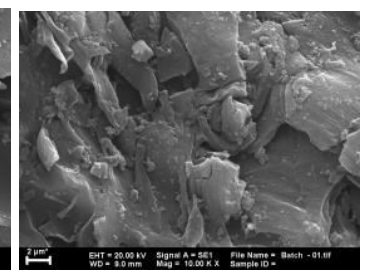

(d)
Gambar (a) \& (c) Analisa SEM sebelum proses adsorpsi, Gambar (b) \& (d) setelah proses adsorpsi.

Sumber: Analisa SEM-Laboratorium Energi-ITS

Pada Gambar (a) \& (c) merupakan mikrograf SEM karbon aktif sebelum proses adsorpsi. Sedangkan pada Gambar (b) \& (d) setelah terjadinya proses adsorpsi. Analisa SEM dilakukan pada perbesaran 1.000 kali dan 10.000 kali. Hasil analisa menunjukkan pori karbon aktif sudah tertutupi oleh adsorbat yang teradsorp pada permukaan karbon aktif. Perbedaan pada keseluruhan gambar terlihat pada selaput yang terlihat menutupi pori di seluruh permukaan karbon aktif. Untuk perbedaan yang lebih jelas seperti perbedaan warna tidak dapat ditampilkan pada hasil SEM. Karena analisa SEM itu sendiri hanya untuk mengetehui permukaan objek padatan. Perbedaan warna antara adsorbat dengan adsorben dapat diketahui melalui analisa lebih lanjut dengan menggunakan analisa EDX. Namun penelitian ini hanya dibatasi pada analisa SEM. Berdasarkan dari keseluruhan hasil analisa SEM menyatakan bahwa proses adsorpsi yang terjadi pada penelitian ini merupakan adsorpsi multilayer. Hal ini dijelaskan dengan pori yang terdapat pada permukaan luar dan beberapa permukaan dalam (berupa cekungan/retakan) yang lebih dalam lagi. Hal ini mendukung hasil perhitungan isoterm model $B E T$ yang mengasumsikan adsorpsi yang terjadi secara fisika dan multilayer.

\section{KESIMPULAN/RINGKASAN}

Berdasarkan Tugas Akhir yang telah dilakukan oleh penulis, dapat ditarik kesimpulan sebagai berikut:

1. Penyisihan COD terbesar sebanyak $16.444,08 \mathrm{mg} / \mathrm{L}$. Persentase penyisihan mencapai sebesar 98,74\% pada waktu kontak 2,5 jam. Penyisihan BOD terbesar sebanyak 1.640,70 mg/L. Persentase penyisihan sebesar 92,30\% pada waktu kontak 2,5 jam.

2. Jumlah adsorben karbon aktif yang digunakan efektif untuk menurunkan pencemar organik baik BOD dan COD adalah sebesar 190 gram. Dan waktu kontak 2,5 jam menunjukkan penyisihan COD dan BOD terbesar.

3. Hasil analisis SEM menunjukkan bahwa pori-pori yang mulanya masih kosong telah tertutupi oleh adsorbat yang teradsorpsi. Proses adsorpsi yang terjadi pada penelitian ini merupakan adsorpsi multilayer.

4. Didapatkan isoterm yang paling tepat adalah isoterm BET. Dengan nilai $\mathrm{Y}=0,5881 \ln (\mathrm{x})+2,22$ dan nilai Regresinya 0,8295. Mengasumsikan adsorpsi yang terjadi secara fisika dan multilayer.

\section{UCAPAN TERIMA KASIH}

Penulis mengucapkan terima kasih kepada Direktorat Pendidikan Tinggi, Departemen Pendidikan dan Kebudayaan Republik Indonesia yang telah memberikan dukungan finansial melalui Beasiswa Bidik Misi tahun 2012-2016.

\section{DAFTAR PUSTAKA}

[1] I. Purwaningsih, "Pengolahan Limbah Cair Industri Batik CV. Batik Indah Raradjonggrang Yogyakarta Dengan Metode Elektrokoagulasi Ditinjau Dari Parameter Chemical Oxygen Demand (COD) Dan Warna," Universitas Islam Indonesia, 2008.

[2] Balai Riset dan Standarisasi Industri, "Pengujian Karakteristik Limbah Batik," Surabaya, 2016.

[3] A. Kurniawan and W. Eguh, "Uji Coba Penjernihan dan Pengilangan Bau Limbah Tapioka dengan Menggunakana Karbon Aktif dari (Studi Aktivasi dan Pengasaman)," Institut Teknologi Sepuluh Nopember, 2008.

[4] Gubernur Jawa Timur, "Peraturan Gubernur Jawa Timur tentang 
Baku Mutu Air Limbah no 72,” 2013.

[5] M. A. Yusuf and S. Tjahjani, "Adsorpsi Ion $\mathrm{Cr}(\mathrm{VI})$ oleh Arang Aktif Sekam Padi," UNESA J. Chem., vol. 2, no. 1, pp. 84-88,
2013.

[6] SII, "Syarat Mutu dan Uji Karbon Aktif," Palembang. 